\title{
Characterization of the sand of Brahmaputra river of Bangladesh
}

\author{
Md. Aminur Rahman ${ }^{\text {, }}$ Pradip Kumar Biswas ${ }^{\text {b }}$, Mohammad Nazim Zaman \\ Md. Yunus Miah' ${ }^{\mathrm{a}}$, Tofazzal Hossain ${ }^{\mathrm{a}}$ and S. M. Imamul Huq ${ }^{\mathrm{a}}$ \\ ${ }^{a}$ Bangladesh Council of Scientific and Industrial Research (BCSIR), Dr. Qudrat-I-Khuda Road, Dhanmondi, \\ Dhaka 1205, 'bnstitute of Mining, Mineralogy and Metallurgy (IMMM), Bangladesh Council of Scientific and \\ Industrial Research (BCSIR), Science Laboratory Road, Khonjonpur, Joypurhat 5900.
}

\begin{abstract}
The aim of this paper is to study on the mineralogy, morphology, magnetic property and composition of the sand of Brahmaputra River, Bangladesh. The sand has been collected from randomly selected seven places and separated by High Intensity Rolling Magnetic Separator into three fractions, viz. magnetic, para-magnetic and non-magnetic parts. The identifications of the valuable heavy minerals existing in these fractions have been performed. The valuable heavy minerals in the separated fractions have been counted under reflected and polarizing microscope and it is found that the magnetic fraction contains ilmenite, magnetite and garnet. The major grain size fraction of the magnetic fraction is $125-250 \mu \mathrm{m}(57.18 \%)$. Zircon, rutile, xenotime, monazite, sillimanite etc. have been counted in other two fractions. X-ray Diffraction (XRD), X-ray Fluorescence (XRF) and Isodynamic Separator have been applied for mineral assessment and to quantify the relative proportion of mineral species.
\end{abstract}

Key words: Brahmaputra, Magnetite, Sediment, Ilmenite, Rutile

\section{Introduction}

The Brahmaputra River originating in Tibet and flowing through Tibet and the north-eastern part of India enters Bangladesh in Nagaswari Thana of Kurigram District (Fig. $1)$. The system is a very large scale sand bed braided river (Coleman, 1969) of a $15 \mathrm{~km}$ width with individual channels of 2-3 km wide. His bed level has an elevation of $7-20 \mathrm{~m}$ above the sea level (Rahman 1972). The River carries 7.35$8.00 \times 10^{8}$ ton of sediment every year. The sediment contains large quantity of sandy materials, which are generally laid down on the bed of the river, forming sand bars. The thickness of sand deposits up to gravel bed is $44 \mathrm{~m}$ (Umitsu 1991). Alluvial sediments contain both light and heavy minerals in many countries of the world in the coastal areas as well as in land areas. For economic exploitation of mineral sands, it is necessary to identify the minerals present, quantify total reserves of sand deposits, determine the contents and quality of economic minerals, and find the market demands in the country and abroad. The main objective of this study is to work with the magnetic fraction because the concentration of the valuable heavy minerals (VHM) in the magnetic fraction is high and can be separated easily by magnetic separator. Keeping these points in mind, a field trip was made and some sediment samples were collected from *Corresponding author. E-mail:pdyunus@yahoo.com the newly developed sand bars of the Brahmaputra basin to find out the percentage and morphology, mineralogy of valuable heavy minerals present together with the chemical compositions.

\section{Materials and Methods}

The samples seven in number are collected from $1 \mathrm{~m}$ depth and the locations are shown in Fig. 1. The samples have been separated at $60 \mathrm{rpm}$ (magnetic fraction) and $140 \mathrm{rpm}$ (paramagnetic fraction) speed by High Intensity Rolling Magnetic separator. Each sample (100 g) is sieved through a sieve shaker (US sieve 35, 60, 120, 230 and 325) after removing organic matter from the samples by washing several times with $1 \mathrm{~N} \mathrm{HCl}$ followed by distilled water. The visual identification of heavy minerals in the fractions was made by using a polarizing microscope and binocular microscope (under transmitted and reflected light). The every mineral countable in the sample (opaque: such as ilmenite and transparent: such as Zircon, Kyanite, etc.) were estimated by counting a minimum of 200 grains by the ribbon method as described by Mange and Maurer (1991). The mineralogical studies of heavy fractions were also carried out by the Powder XRD 


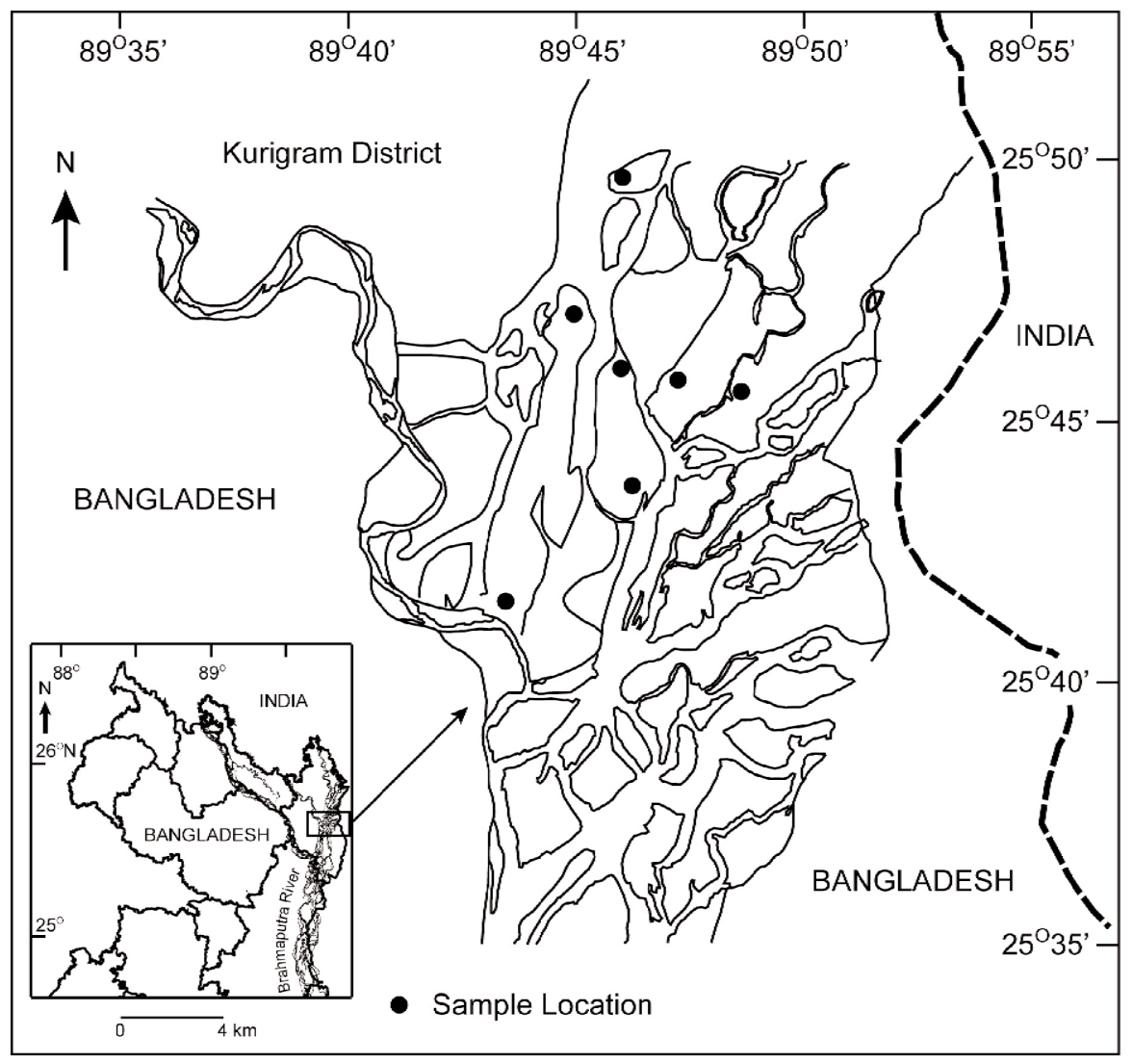

Fig. 1: Location map of the investigated area

analysis and the elemental compositions of heavy fractions were determined by the XRF analysis.

For XRD analysis, a Philips PANalytical X'Pert Pro MPD (PW3040) automated powder diffractometer equipped with a $\mathrm{Cu}-\mathrm{K}_{\alpha}$ radiation source operated at $40 \mathrm{KV}-30 \mathrm{~mA}$ was used. The selected scan range was $10-80^{\circ}$ with a step size of $0.020^{\circ}$ and counting time of $0.50 \mathrm{~s}$. The digital data were interpreted by auto matching with the data available in 'X'Pert High Score Plus' software of the XRD system used.

The elemental compositions were determined by X-ray fluorescence (XRF) Spectrometric method using Rigaku ZSX Primus XRF machine equipped with an end window $4 \mathrm{KW}$ RH - Anode X-ray tube operated at $40 \mathrm{KV}$ - $60 \mathrm{~mA}$ for heavy elements and $30 \mathrm{KV}-100 \mathrm{~mA}$ for light elements. A standard procedure was followed to make sample for XRF analysis (Goto and Tatsumi 1994, 1996).

\section{Results and Discussion}

\section{Magnetic separation}

Seven samples on magnetic separation by High Intensity Rolling Magnetic Separator show that the amount of mag- netic fraction varies from $6.63 \%$ to $18.86 \%$; whereas, the amount of para-magnetic fraction varies from $7.95 \%$ to $16.17 \%$ (Table I). The grain size distribution shows that the predominant $(57.18 \%)$ size is in the rank of $125-250 \mu \mathrm{m}$ in the magnetic fraction. Similarly, $60.37 \%$ and $64.5 \%$ of paramagnetic and non-magnetic fractions, respectively, have the grain size of above range (Table II). It is noticed that mag-

Table I: The percentages of magnetic, para-magnetic and non-magnetic fractions which are separated by High Intensity Rolling Magnetic Separator

\begin{tabular}{lccc}
\hline $\begin{array}{l}\text { Sample } \\
\text { No. }\end{array}$ & $\begin{array}{c}\text { Magnetic } \\
\text { part }(\%)\end{array}$ & $\begin{array}{c}\text { Para-Magnetic } \\
\text { part }(\%)\end{array}$ & $\begin{array}{c}\text { Non-Magnetic } \\
\text { part }(\%)\end{array}$ \\
\hline 1 & 10.53 & 10.52 & 78.95 \\
2 & 6.63 & 7.95 & 85.42 \\
3 & 13.49 & 11.73 & 74.78 \\
4 & 9.96 & 10.72 & 79.32 \\
5 & 12.50 & 12.50 & 75.00 \\
6 & 11.76 & 10.59 & 77.65 \\
7 & 18.86 & 16.17 & 64.97 \\
Average & 11.96 & 11.45 & 76.58 \\
\hline
\end{tabular}


netite is assembled mainly in $45-63 \mu \mathrm{m}$ sized fraction; whereas, ilmenite is assembled mainly in $63-250 \mu \mathrm{m}$ sized fractions of magnetic part.

Table II: The grain size distribution among the magnetic, para-magnetic and non-magnetic fractions

\begin{tabular}{lccc}
\hline $\begin{array}{l}\text { Grain size } \\
\text { ranges } \mu \mathrm{m}\end{array}$ & $\begin{array}{c}\text { Magnetic } \\
\text { part (\%) }\end{array}$ & $\begin{array}{c}\text { Para-Magnetic } \\
\text { part (\%) }\end{array}$ & $\begin{array}{c}\text { Non-Magnetic } \\
\text { part (\%) }\end{array}$ \\
\hline $250-500$ & 13.63 & 13.70 & 10.02 \\
$125-250$ & 57.18 & 60.37 & 64.5 \\
$63-125$ & 24.29 & 23.33 & 20.45 \\
$45-63$ & 3.55 & 1.85 & 3.75 \\
Pan & 1.33 & 0.74 & 1.25 \\
\hline
\end{tabular}

\section{Grain counting by microscope}

The binocular and polarizing microscopes are used to identify the valuable minerals in the magnetic, para-magnetic and non-magnetic fractions. Ilmenite (5.95\%), garnet (8.84\%) and magnetite $(4.65 \%)$ are identified in the magnetic fraction. Ilmenite $(3.60 \%)$ and garnet $(2.74 \%)$ are also identified in the para-magnetic fraction associated with monazite $(1.35 \%)$, zircon $(0.34 \%)$, chlorite $(2.59 \%)$ and kyanite $(5.22 \%)$. The grains of ilmenite and garnet that are found in the para-magnetic fractions are usually weathered and
Table III: The percentages of minerals in the magnetic, para-magnetic and non-magnetic parts

\begin{tabular}{lccc}
\hline Mineral & $\begin{array}{c}\text { Magnetic } \\
\text { Name }\end{array}$ & $\begin{array}{c}\text { Para-Magnetic } \\
\text { Part }\end{array}$ & $\begin{array}{c}\text { Non-Magnetic } \\
\text { Part }\end{array}$ \\
\hline Chlorite & 0 & 2.59 & 0 \\
Garnet & 8.84 & 2.74 & 0 \\
Ilmenite & 5.95 & 3.6 & 0 \\
Kyanite & 0 & 5.22 & 0 \\
Magnetite & 4.65 & 0 & 0 \\
Monazite & 0 & 1.35 & 0.28 \\
Rutile & 0 & 0 & 1.36 \\
Sillimanite & 0 & 0 & 3.1 \\
Xenotime & 0 & 0 & 1.95 \\
Zircon & 0 & 0.34 & 1.42 \\
Quartz & 0 & 31.01 & 72.24 \\
Feldspar & 2.21 & 5.27 & 5.76 \\
Mica & & & \\
(Muscovite & & & \\
+ Biotite) & 31.01 & 14.02 & 5.89 \\
Hornblende & 12.72 & 13.2 & 2.45 \\
Pyroxene & 16.28 & 11.25 & 0 \\
Olivine & 7.34 & 2.48 & 0 \\
Hematite & 5.23 & 0 & 0 \\
Others & 5.77 & 6.93 & 5.55 \\
\hline Total & 100 & 100 & 100 \\
\hline
\end{tabular}

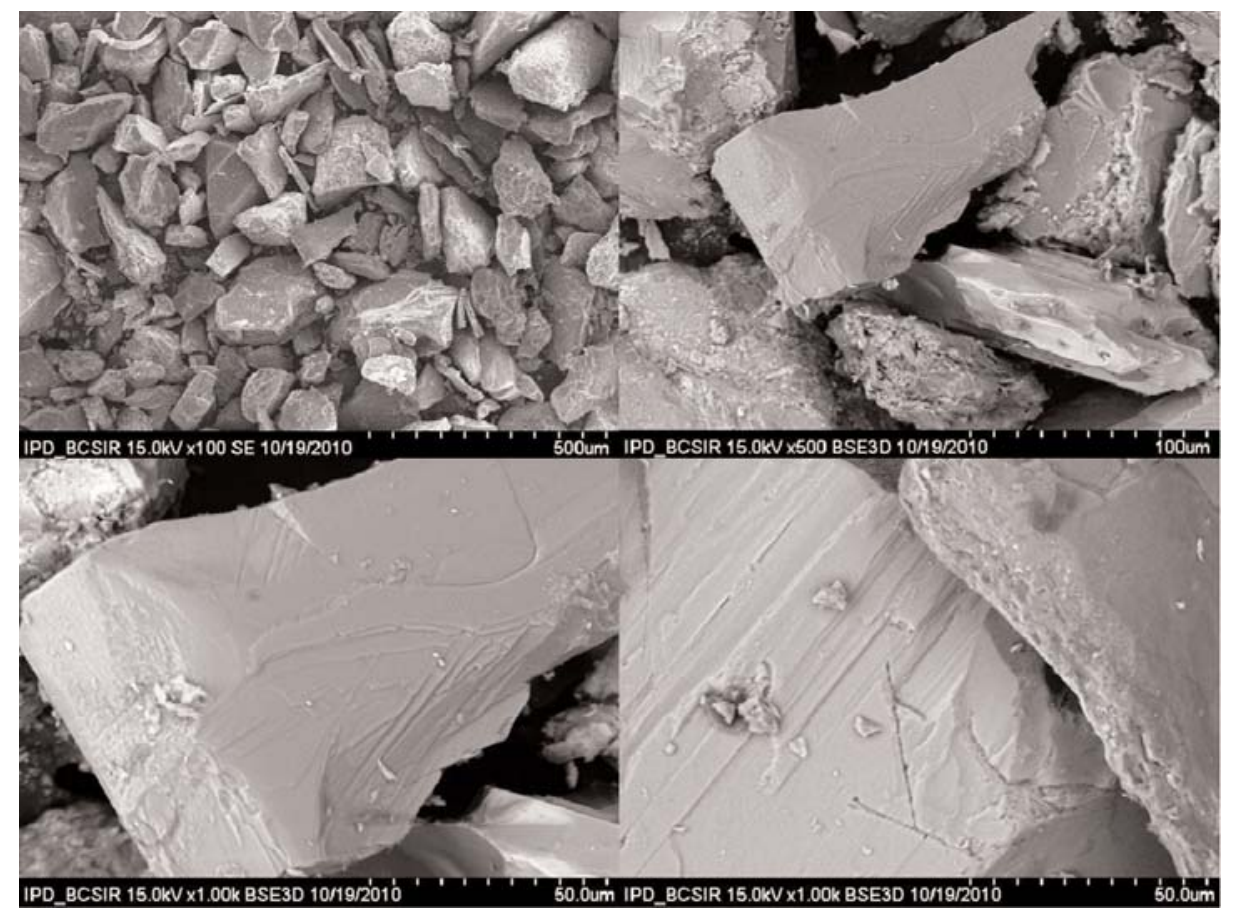

Fig. 2: SEM Photographs of Magnetite. The grains are mostly inclusions free 
altered. Because of weathering and alteration these grains have lost Fe and become less magnetic. The opaque mineral, magnetite can be separated by a hand magnet and usually concentrates in the magnetic fraction. The other non-magnetic valuable minerals, viz. zircon $(1.42 \%)$, rutile $(1.36 \%)$, xenotime $(1.95 \%)$ and sillimanite $(3.10 \%)$ are identified in

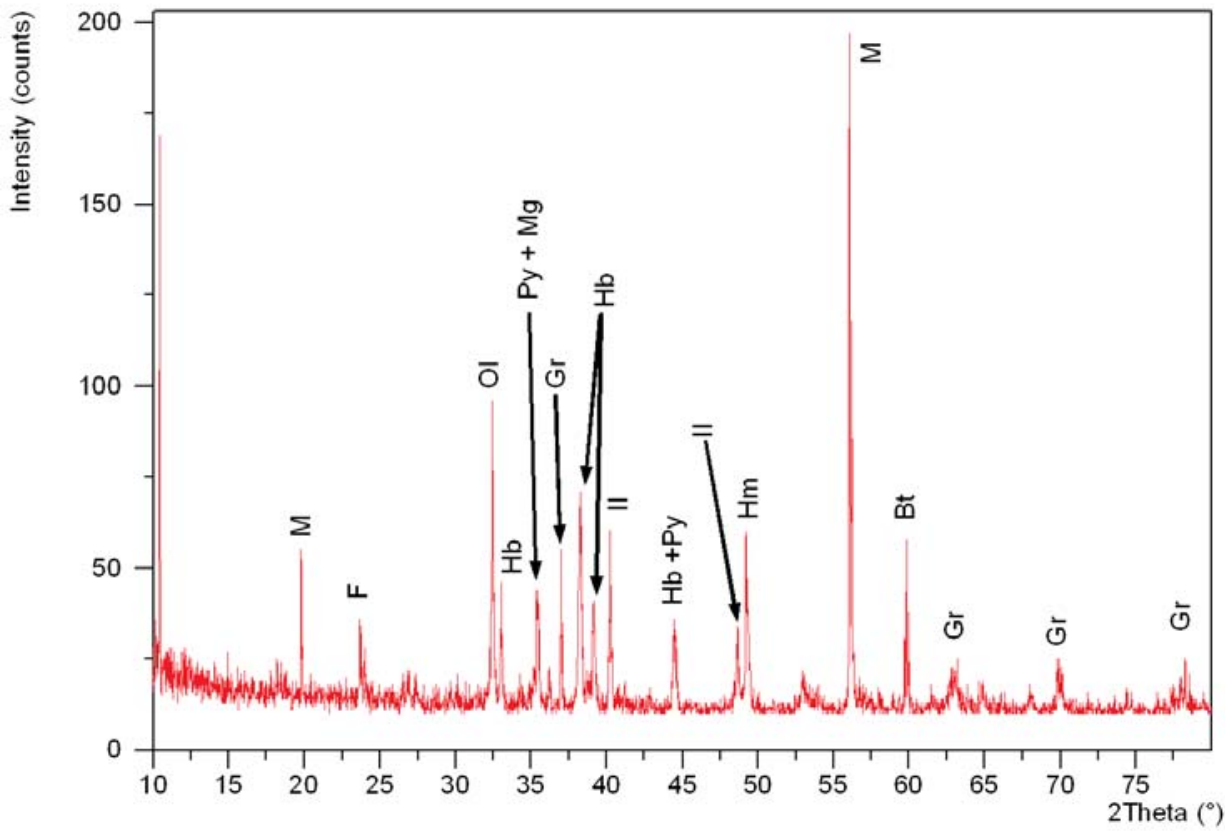

Fig. 3(a): XRD Pattern for the magnetic part of the sand of Brahmaputra river.

$\mathrm{M}=$ Muscovite, $\mathrm{F}=$ Feldspar, $\mathrm{Ol}=$ Olivine, $\mathrm{Hb}=$ Hornblende, $\mathrm{Py}=$ Pyroxene, $\mathrm{Mg}=$ Magnetite, $\mathrm{Gr}=\mathrm{Garnet}$, $\mathrm{Il}=$ Ilmenite, $\mathrm{Hm}=$ Hematite and $\mathrm{Bt}=$ Biotite

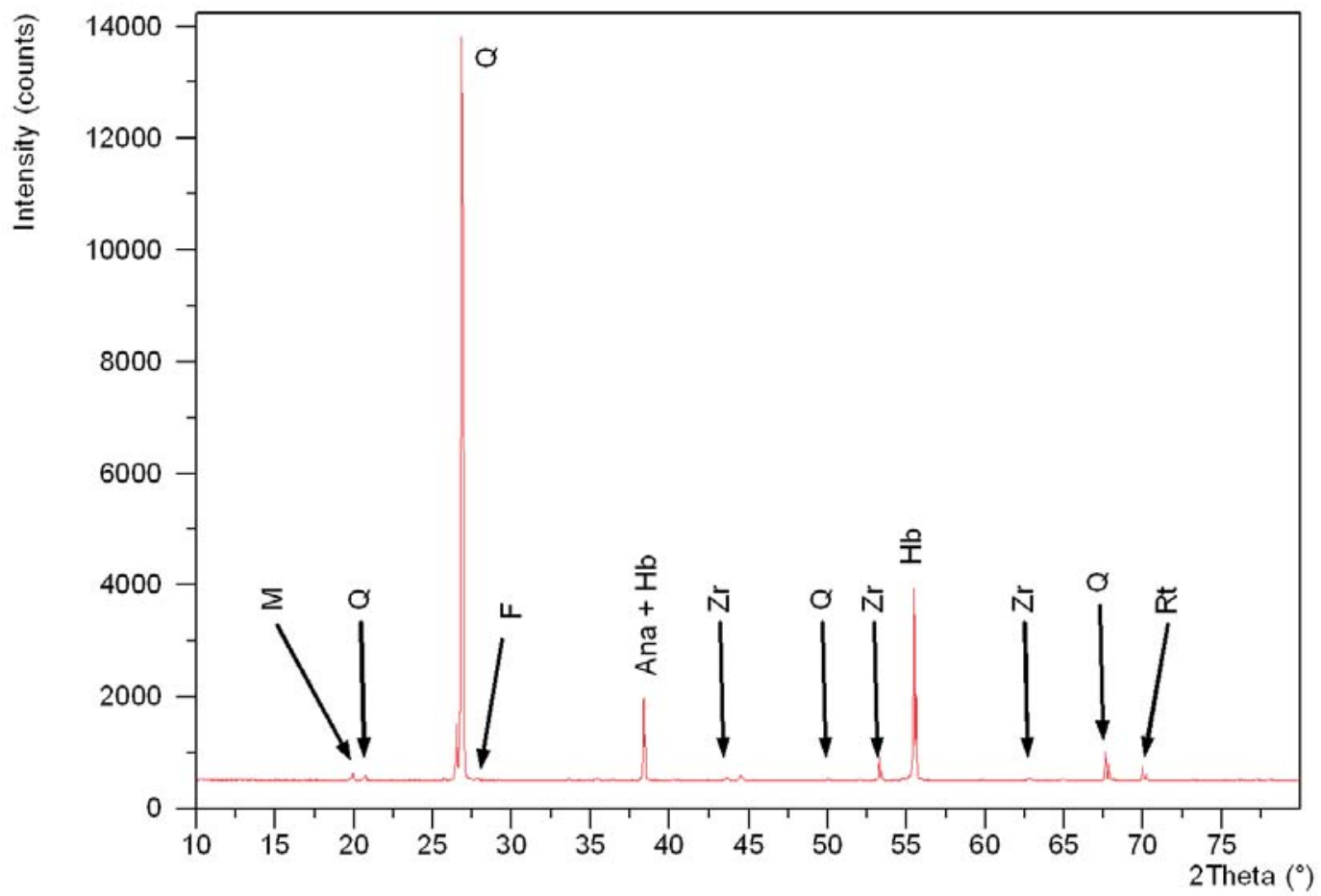

Fig. 3(b): XRD Pattern for the para-magnetic part of the sand of Brahmaputra river

$\mathrm{F}=$ Feldspar, $\mathrm{Ol}=$ Olivine, $\mathrm{Hb}=$ Hornblende, $\mathrm{Py}=$ Pyroxene, $\mathrm{Gr}=$ Garnet, $\mathrm{Il}=$ Ilmenite, $\mathrm{Bt}=$ Biotite, $\mathrm{Q}=$ Quartz, Mon = Monazite and Kya $=$ Kyanite 
the non-magnetic fraction (Table III). The SEM photograph of the magnetite grain shows that it is mostly fresh, unaltered and inclusion free (Fig. 2).

\section{Phase identification}

There are a large number of different minerals present, many of which have overlapping peaks, making identification challenging by XRD method. XRD analysis of the non-magnetic part reveals that the solids are predominately quartz (intensity counts is high in contrast with other phases and also other fractions) with a significant number of minor phases of feldspar, zircon, mica, hornblende, rutile, anatase (Fig. 3a). The XRD method of phase identification is consistent with microscopic study and as well as XRF analysis. The XRD pattern of para-magnetic part identifies mainly the phases of quartz, feldspar, hornblende, monazite, olivine, ilmenite, biotite, kyanite and garnet (Fig. 3b). The maximum intensity of the magnetic part predominantly shows muscovite along with magnetite, ilmenite, biotite, garnet, olivine, pyroxene, hornblende and hematite (Fig. 3c).

\section{Elemental analysis}

The elemental composition of three fractions reflects the overall chemistry of minerals contained in the fractions. Such information is useful to identifying fractions of mineralogi-
Table IV: The chemical composition of the magnetic, para-magnetic and non-magnetic parts

\begin{tabular}{lccc}
\hline & \multicolumn{3}{c}{ Sample Name } \\
\cline { 2 - 4 } Element & $\begin{array}{c}\text { Magnetic } \\
\text { Part }(\mathrm{Wt} \%)\end{array}$ & $\begin{array}{c}\text { Para-Magnetic } \\
\text { Part }(\mathrm{Wt} \%)\end{array}$ & $\begin{array}{c}\text { Non-Magnetic } \\
\text { Part (Wt\%) }\end{array}$ \\
\hline $\mathrm{Na}_{2} \mathrm{O}$ & 0.249 & 1.29 & 2.196 \\
$\mathrm{MgO}$ & 12.01 & 4.222 & 0.284 \\
$\mathrm{Al}_{2} \mathrm{O}_{3}$ & 16.92 & 14.919 & 8.039 \\
$\mathrm{SiO}_{2}$ & 39.132 & 62.14 & 76.954 \\
$\mathrm{P}_{2} \mathrm{O}_{5}$ & 0.076 & 0.227 & 0.161 \\
$\mathrm{~K}_{2} \mathrm{O}$ & 4.946 & 3.495 & 2.289 \\
$\mathrm{CaO}_{\mathrm{TiO}}$ & 1.682 & 1.68 & 1.177 \\
$\mathrm{Fe} \mathrm{O}_{3}$ & 2.368 & 0.795 & 0.151 \\
$\mathrm{~V}$ & 21.604 & 6.874 & 0.409 \\
$\mathrm{Mn}$ & 0.0281 & 0.0095 & 0.0004 \\
$\mathrm{Rb}_{\mathrm{Sr}}$ & 0.3087 & 0.0808 & 0.0072 \\
$\mathrm{Zr}$ & 0.0309 & 0.0177 & 0.01 \\
$\mathrm{Ba}$ & 0.0002 & 0.0091 & 0.0117 \\
$\mathrm{Th}$ & 0.0157 & 0.0644 & 0.0274 \\
$\mathrm{Hf}$ & 0.0615 & 0.0423 & 0.0229 \\
$\mathrm{Sc}$ & - & 0.0052 & 0.0038 \\
$\mathrm{U}$ & 0.0003 & 0.0003 & 0.0003 \\
& 0.0042 & 0.0014 & - \\
$\mathrm{Fe}$ & 0.0001 & 0.0002 & 0.0002 \\
& 99.44 & 95.87 & 91.74 \\
\hline & & &
\end{tabular}

$\mathrm{Fe}_{2} \mathrm{O}_{3}=$ Total iron oxide

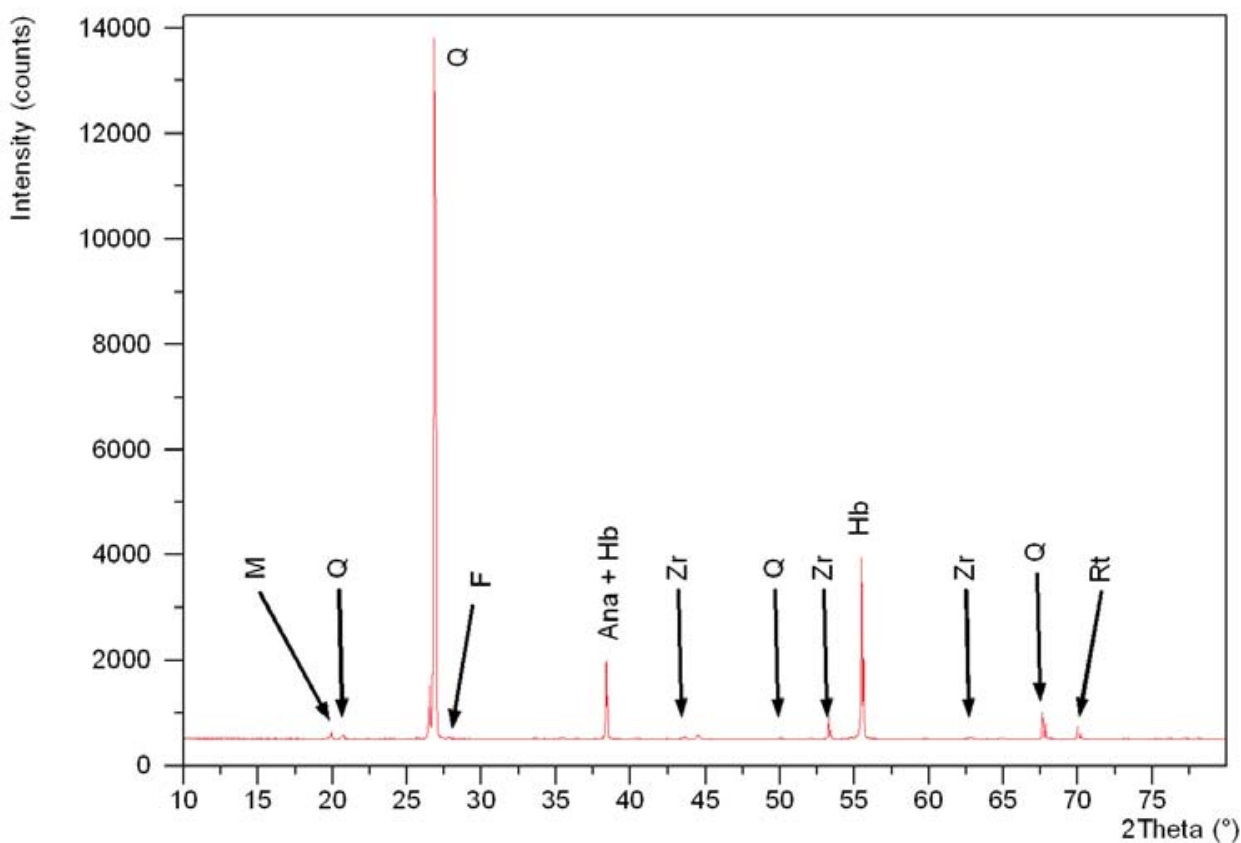

Fig. 3(c): XRD Pattern for the non-magnetic part of the sand of Brahmaputra river

$\mathrm{M}=$ Muscovite, $\mathrm{F}=$ Feldspar, $\mathrm{Hb}=$ Hornblende, $\mathrm{Q}=$ Quartz, Ana $=$ Anatase, $\mathrm{Zr}=$ Zircon and Rt $=$ Rutile 
cal interest. The elemental composition of the fractions determined by XRF analysis is given in Table IV. From this study it is observed that the marked enrichment of iron oxide (21.604\%) and titanium oxide (2.368\%) together with inclusion of lesser amount of silicon oxide (39.132\%) occur in the magnetic part than in other two parts.

\section{Conclusions}

The present study shows the magnetic properties of the sand of Brahmaputra River and identifies it as a source of Fe and Ti bearing minerals magnetite and ilmenite which are economically valuable and huge demand in the international market. The Al, K, Mg, Si bearing minerals (e.g. olivine, pyroxene, hornblende, mica etc.) can not be separated easily by physical separation method and are less economically valuable in contrast with magnetite and ilmenite through physical separation. It is found that the magnetic fraction is important because the concentration of valuable minerals in it is high and can be separated easily from other two fractions. The concentration of valuable heavy minerals in the sand of the Brahmaputra river is remarkable. The heavy minerals ilmenite $(5.95 \%)$, garnet $(8.84 \%)$, magnetite $(4.65 \%)$ are enriched in the magnetic fraction while zircon $(1.42 \%)$, rutile $(1.36 \%)$ are enriched in the non-magnetic fraction. On the basis of the minerals ilmenite and magnetite as main products and other minerals zircon, rutile, garnet, sillimanite etc. may be bi-product; a mine and a mineral separation plant can be developed in the Nagaswari Thana of Kurigram district where the Brahmaputra river enters Bangladesh. For this purpose, a comprehensive study is required to assess the reserve estimation and have to setup a pilot plant before establishing a mine and mineral separation plant.

\section{Acknowledgement}

The authorities of BCSIR are thankfully acknowledged for providing research grant for the present work. The authors are thankful to the Director and Mr. S. F. Farhad, BCSIR Laboratories, Dhaka for SEM photographs. Authors are extremely grateful to other scientists, technicians and other laboratory attendants of the institute for their helps during field work, sample preparation and analytical services.

\section{References}

Coleman JM 1969. Brahmaputra River: Channel Process and sedimentation. Sed. Geol, 3(213): 239.

Goto A and Tatsum Y 1994. Quantitative analysis of rock samples by an X-ray fluorescence spectrometer (I). The Rigaku Jour 11(1): 40-59.

Goto A and Tatsum Y 1996. Quantitative analysis of rock samples by an x-ray fluorescence spectrometer (II). The Rigaku Jour 13(2): 20-39.

Mange A M and Maurer HEW 1991. Schwerminerale in Farbe, Ferdinand Enke Verlag Stuttgart, Germany, p. 148.

Rahman MA 1972. Flood Control and Sediment Transportation of the Rivers of Bangladesh, p. 153158. Proceedings of the Seminar on Flood Control.

Umitsu M 1987. Late Quaternary sedimentary environment and landform evolution in the Bengal lowland: Geographical Review of Japan, 60: 164-178.

Manuscript received on 12 October 2011; revised on 19 December 2011; accepted on 10 April 2012. 